\title{
Petiole anatomy of Indian species of the genera Smilax L. and Heterosmilax Kunth. (Smilacaceae).
}

\section{S. Baruah ${ }^{*}$, D. Baro ${ }^{2}$ and S. K. Borthakur ${ }^{3}$}

${ }^{1}$ Department of Botany, Bodoland University, Kokrajhar - 7833 70, Assam, India

2,3Department of Botany, Gauhati University, Guwahati- 7810 14, Assam, India.

Received: 7/22/2016; Revised: 8/19/2016; Accepted: 9/24/2016

\begin{abstract}
Petiole anatomy of 12 species, 11 species of Smilax L. and one species of Heterosmilax Kunth., of the family Smilacaceae have been studied. Anatomical features of the petiole provide supporting evidences for the infraspecific circumscription of the occurring in India.
\end{abstract}

Keywords: Petiole anatomy, taxonomy, Smilax, Heterosmilax, India

\section{Introduction}

Smilax L. (1753: 1028) is the type genus of family Smilacaceae, with ca. 350 species [1] mainly distributed in tropical and temperate areas throughout the world, but mostly confined to Asia and America [2]. The genus Heterosmilax is a small south eastern Asiatic genus that is closely allied to the genus Smilax [3]. Heterosmilax is comprised of about 11 species recorded from southern China, Myanmar, Thailand, Indo-China, and western Malaysia, with one species extending to the Ryukyu Archipelago, and Assam and Khasia in India [4]. In India the family represented by 33 species of Smilax L. and another four species viz., S. collina, S. decipiens, S. obliqua and $S$. singeporensis as doubtful species and two species viz., S. wallchi, S. villandia as imperfectly known species [5]. Out of 33 species reported by Hooker only 24 are from the present political boundary of India which includes five species from South India and 17 from northeast India [6]. However, like other monocots of NE India the Smilacaceae is yet to be properly documented and studied. Recently, from north eastern part of India several important studies have been performed on genus Smilax and Heterosmilax [7-9].

The identity of the genus Smilax is often difficult due to close morphological similarity of the species and dioecious nature of the plants. Most often it is unlikely that both male and female plants occur in the same locality and this very often leads to difficulty in ascertaining the proper identity of the members of the genus. Reproductive characters often are also not reliable for species delimitation [10]. Therefore, alternative attributes are required to resolve identity of the species with certainty.

In recent years, anatomical characters including the petiole characters have been widely used in solving taxonomic problems in vascular plants [11-15]. The

${ }^{*}$ Corresponding Author:

Dr. Sanjib Baruah,

Asst. Professor \& HOD,

Dept. of Botany, Bodoland University, India.

E-mail: sanjibbaruah9@gmail.com structure of petiole shows differences between genera and species. In the present study, anatomical characters of the petiole of 12 species belonging to the family Smilacaceae were examined and compared.

\section{Materials and Methods}

Plant materials were collected from different localities of Northeastern India (Table 1). The collected plant materials were fixed in F.A.A. and then preserved in $70 \%$ alchohol. Permanent transverse hand sections of middle part of petiole were made and stained with Safranin and Fast Green [16] dehydrated with an ethanol gradient $(70 \%$ in three steps to $100 \%)$ and finally incubated in xylol $(99.5 \%)$. The stained dehydrated sections were then mounted on slides using DPX and studied under bionocular research and compound Nikon microscope

\section{Results and Discussion}

Cross sections of petioles are shown in Plate No. I, Figs. a-i. There are three kinds of tissue in each cross section (Figs. a-i). The exterior parenchymatous cortical tissue at the periphery of petiole is bounded by a single layer of epidermis. The centre of the petiole is occupied primarily by parenchymatous ground tissue. Vascular bundles are the third tissue.

\section{Smilax perfoliata [Fig. a]}

The petiole in t.s. is shallowly grooved with two short acuminate lateral outgrowths and acuminate in abaxial surface. Epidermis comprises of single layer of isodiametric cells. The 20-25 randomly distributed vascular bundles of variable size are confined to the central part of the petiole and are of different in size. 


\section{Smilax ovalifolia [Fig. b]}

In t. s. the adaxial side of the petiole is deeply grooved with two wide obtuse lateral projections, whereas the abaxial face is acute. Epidermis consists of single layer isodiametric cells. The hypodermis is irregular in thickness and comprises of isodiametric parenchymatous cells with dark cell content. The 45-50 conjoint, collateral vascular bundles of variable size are randomly distributed and surrounded by 3-4 layers of sclelerenchyma.

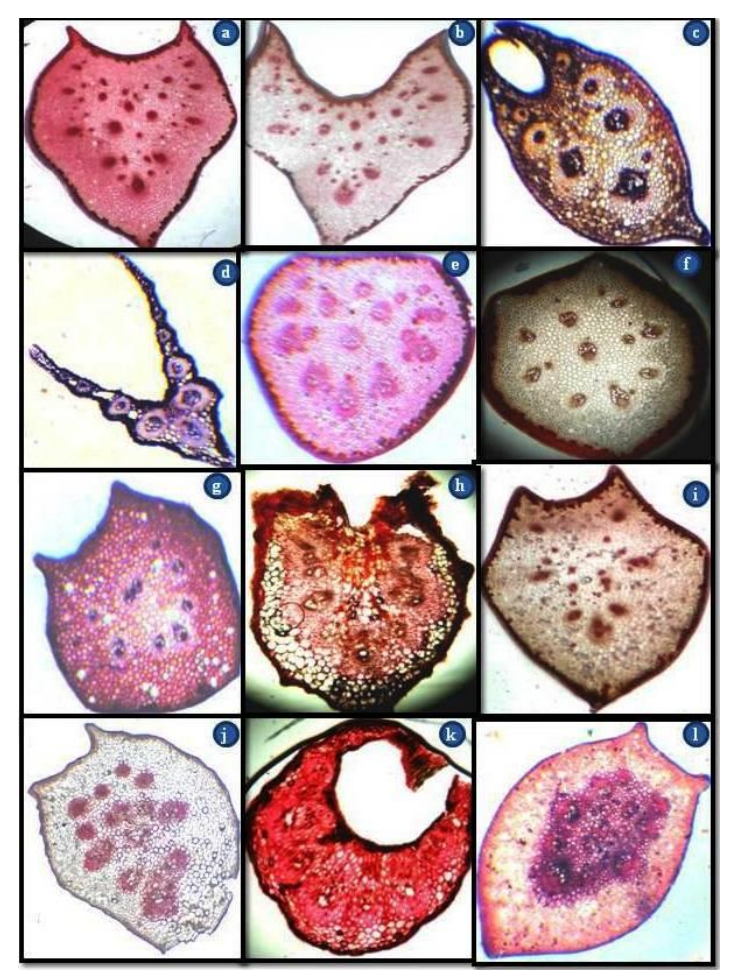

Plate No. I; Figures (a-i); (a) S. perfoliata $\times 20$, (b) $S$. ovalifolia $\times 20$, (c) S. glabra $\times 20$, (d) S. china $\times 20$, (e) $S$. orthopera $\times 20$, (f) S. ocreata $\times 20,(\mathrm{~g})$ S. lanceifolia $\times 20$, (h) S. aspericaulis $\times 20$, (i) S. arisanensis $\times 20$, (j) S. zeylanica $\times$ 20, (k) Smilax sp. $\times 20$, (l) Heterosmilax japonica $\times 20$.

\section{Smilax glabra [Fig. c]}

In t. s. the adaxial side of the petiole is deeply grooved with two lateral projections touching each other by their margins and the abaxial side is nearly acuminate. The epidermis comprises of single layer of oval cells with thick cuticle. Hypodermis is of two layers of chlorenchymatous cells. Of eight scattered vascular bundles three are big and five are small. Each vascular bundle is surrounded by $2-3$ layers of sclerenchyma.

\section{Smilax china [Fig. d]}

In t. s. the adaxial side of the petiole exhibit a deep groove with two very long tapering lateral outgrowths and narrowly acute abaxial side. Epidermis is single layered with well developed cuticle. The seven or eight vascular bundles are arranged linearly in descending order by their size and encircled by 3-4 layers of sclerenchymatous cells.

\section{Smilax orthoptera [Fig. e]}

In t. s. petiole is flat on adaxial side without lateral projections and almost round on abaxial side. Epidermis is of single layer with thin cuticle. The hypodermis is of two-layers of chlorenchymatous cells. The 12-13 vascular bundles of variable size are arranged in two circles around a central zone.

\section{Smilax ocreata [Fig. f]}

In cross section the adaxial side of the petiole is horizontally flat and nearly round on adaxial side. The single epidermal layer has thin exterior cuticle layer. Hypodermis varies in thickness with dark cell content. The 20-22 conjoint, collateral vascular bundles of variable size are randomly distributed and are surrounded by 3-4 layers of schlerenchyma.

\section{Smilax lanceifolia [Fig. g]}

The outline of the petiole in t.s is horse-shoe shaped with a shallow groove on adaxial side and abruptly acute on abaxial side. Epidermal cells are circular and cutic layer is thick. Hypodermal layer is absent. The numbers of vascular bundles are 8-10 and are of different size.

\section{Smilax aspericaulis [Fig. $\mathrm{h}$ ]}

The outline of the petiole in t.s is slightly wavy forming angles at points with adaxial side forming a $\mathrm{v}$-shaped groove and acuminate on abaxial side. The epidermal cells are cutinized, irregular in sized and several layerd on the adaxial side but numbers of layers on lateral and abaxial sides are less. The 6-7 vascular bundles of variable size are encircled by 3-4 layers of sclenchyma. Tanniniferous cells are distributed in ground tissue and in vascular bundles.

\section{Smilax arisanensis [Fig. i]}

The outline of the petiole in t. s. is circular with shalowly u-shaped groove on the adaxial side and acuminate on the abaxial side. The epidermal layer is single cell thick and cuticle is thin. Hypodermis is single layered and number of vascular bundle of variable size is $18-20$.

\section{Smialx zeylanica [Fig. j]}

The adaxial side of the petiole in t. s. is slightly inclined with two unequal lateral projections and acuminate on abaxial side. Epidermis consists of single layer of thick-walled oval cells with thick cuticle. Hypodermis is distinct and consists of either single or double layers. Numbers of vascular bundles are 14-16 and their size is variable.

\section{Smilax sp. [Fig. k]}

As exhibited in t. s. the adaxial side of the petiole is deeply grooved with two lateral projections overlapping each other and the abaxial face is round. Epidermis consists of single layer of thickwalled round cells with cuticle. The 5-7 variable size vascular bundles are arranged in a liner pattern and each of them are surrounded by 3-4 layers of sclerenchyma. 
Heterosmilax japonica [Fig. 1]

Adaxial face of the petiole as exhibited in t. s. shallowly grooved with two short lateral projections and acuminate on abaxial side. The epidermis is consisting of single layer followed by 10-12 layers of parenchymatous cortex. The numbers of vascular bundles are 10-12 and their sizes are different.

Scrutiny of the literature revealed that no work has so far been done on anatomy of petiole of species of Smilax and Heterosmilax. Data obtained from the present study shows that anatomy of the petiole can be used for proper identification of these species. The significant attributes of the petioles for taxonomic use include outlines of the petioles (Plate No I, Figs. a - 1; Table 2). The deeply grooved petiole on adaxial face has been recorded in Smilax glabra, S. ovalifolia, S. arisanensis, Smilax sp. and shallow grooved petiole is found only in $S$. orthoptera (Fig. e) and S. ocreata (Fig. f) and H. japonica (Fig. l). Likewise, acuminate outline of petiole on abaxial face has been recorded in Smilax china, S. glabra,
S. ovalifolia, S. aspericaulis, S. arisanensis, Smilax sp. and Heterosmilax japonica. In case of Smilax ocreata and $S$. orthoptera abaxial face have been recorded as round.

The pattern of arrangement of vascular bundles also varies from linear to circular or even scattered among the species studied. The scattered vascular bundle has been recorded in Smilax ovalifolia and $S$. perfoliata. The linear arrangement of the vascular bundle has been recorded in S. china, S. glabra and Smilax sp. The numbers of vascular bundles vary from species to species (Table 2). The vascular tissue is capped by sclerenchyma layer in all the species. Sclerenchymatous layer are continuous in $S$. aspericaulis, Smilax sp. and Heterosmilax japonica. The ground tissue is parenchymatous in all the species studied but it is massive covering the central part except in Smilax china, S. aspericaulis and Smilax sp. The tanniniferous cells are recorded in the cortex and in the ground tissue in S. aspericaulis and Smilax sp. respectively.

Table 1. Localities of studied Smilacaceae taxa.

\begin{tabular}{|c|c|c|}
\hline Locality & GPS Coordinates & Specimen acc. No. \\
\hline Smilax perfoliata Lour. Borkusia chak, Nalbari, Assam & N26022/514/// E91026/.785/// EL $118 m$ & $555\left(\mathrm{GUBH}^{*}\right.$, Assam, India $)$ \\
\hline Smilax ovalifolia Roxb. Khetri, Kamrup, Assam & $\mathrm{N} 26^{0} 08 / 657 / / / \mathrm{E} 092^{0} 10^{\prime} 522^{/ / /}$EL $56.5 \mathrm{~m}$ & 480 (GUBH, Assam, India) \\
\hline Smilax glabra Roxb. Hailakandi, Assam & N 24054/378// /E92045/367//EL $100 \mathrm{~m}$ & 531 (GUBH, Assam, India) \\
\hline Kodh-hati, Ri-Bhoi, Meghalaya & N25048/846/// E92004/894/// EL $1004 \mathrm{~m}$ & 535 (GUBH, Assam, India) \\
\hline Smilax lanceifolia Roxb. Tinsukia, Assam & $\mathrm{N} 27^{0} 26^{\prime} .008 / / /$ E $95^{0} 44 / 393 / / /$ EL $37 \mathrm{~m}$ & 535 (GUBH, Assam, India) \\
\hline Smilax aspericaulis Wall. ex A. DC. Ri Bhoi, Meghalaya & N25051 878" / E091053'096" / EL 551m & 587 (GUBH, Assam, India) \\
\hline Smilax orthoptera A. DC. Karbi Anglong, Assam & $\mathrm{N} 26^{0} 22^{\prime} .164 / / /$ E91026/.733/// EL $119 \mathrm{~m}$ & 651 (GUBH, Assam, India) \\
\hline Smilax ocreata A. DC. North Cacher Hills, Assam & $\mathrm{N} 26^{0} 08 / 757 / / /$ E092 $10 / 753 / / /$ EL $59.5 \mathrm{~m}$ & 487(GUBH, Assam, India) \\
\hline Smilax arisanensis Hayata East Siang, Arunachal Pradesh & N 27036/31.23/// E $94^{0}$ 44/ 43.7/// EL521m & 226(GUBH, Assam, India) \\
\hline East Siang, Arunachal Pradesh & $\mathrm{N} 27^{0} 35^{\prime} 31.23 / / /$ E $94^{0} 43 / 33.63 / / /$ EL $400 m$ & 622 (GUBH, Assam, India) \\
\hline Tinsukia, Assam & $\mathrm{N} 27^{0} 25^{/}$54.5/// E $095^{\circ} 21 / 54.9^{/ / E L 300 m ~}$ & 532 (GUBH, Assam, India) \\
\hline Heterosmilax japonica Kunth Karbi Anglong, Assam & N2603051" /E093043'51" / EL143m & 538 (GUBH, Assam, India) \\
\hline
\end{tabular}

Table 2. Comparative petiole anatomical features of the studied species

\begin{tabular}{|c|c|c|c|c|c|c|c|c|}
\hline Taxa & $\begin{array}{c}\text { Shape of the petiole } \\
\text { Adaxial }\end{array}$ & $\begin{array}{c}\text { Nature of cuticle } \\
\text { Abaxial }\end{array}$ & Hypodermis & $\begin{array}{l}\text { Sclerenchyma layers in } \\
\text { vascular bundle }\end{array}$ & $\begin{array}{l}\text { No. vascular } \\
\text { bundle layer }\end{array}$ & $\begin{array}{l}\text { Larger } \\
\text { size }\end{array}$ & $\begin{array}{l}\text { Small } \\
\text { size }\end{array}$ & $\begin{array}{c}\text { Arrangement of } \\
\text { vascular bundles }\end{array}$ \\
\hline S.perfoliata & shallowly grooved & acuminate & Thick & single layer & 3-4 layers & 15 & 10 & scatterdly arranged \\
\hline S.china & $\begin{array}{l}\text { deeply groove, } \\
\text { fork shaped }\end{array}$ & acuminate & Thick & not distinguish & 3-4 layers & 3 & 5 & linear \\
\hline S. glabra & deeply grooved & acuminate & Thin & double layer & 2-3 layers & 3 & 8 & linear pattern \\
\hline S. ovalifolia & deeply grooved & acuminate & Thin & single layer & 3-4 layers & 22 & 20 & scatterdly arranged \\
\hline S. orthoptera & flat & round & Thick & double layer & 2-3 layers & 8 & 4 & circular pattern \\
\hline S. ocreata & flat & round & Thick & single layer & 3-4 layers & 11 & 10 & scatterdly arranged \\
\hline S. lanceifolia & horse-shoe shaped & slightly acute & Thin & single layer & 1-2 layers & 8 & 2 & circular pattern \\
\hline S.aspericaulis & slightly wavy & acuminate & Thick & single layer & 5-6 layered & $6-7$ & - & circular arranged \\
\hline S. arisanensis & shallowly u-shaped groove & acuminate & thin & Absent & 3-4 layers & 10 & 8 & scatterdly arranged \\
\hline S. zeylanica & slightly inclined & acuminate & Thin & double layer & $2-3$ layers & 12 & 2 & scatterdly arranged \\
\hline Smilax sp. & deeply grooved O-shaped & round & Thick & Absent & 3-4 layers & 3 & 2 & linear line \\
\hline H. japonica & Flat & acuminate & Thick & 1 layer & 5-6 layers & 4 & 8 & circular line \\
\hline
\end{tabular}

\section{References}

1. Takhtajan AL, Diversity and Classification of Flowering Plants, (ed. 1) Columbia University Press, New York, 1997: 245-256.

2. Chen SC, Qiu YX, Wang AL, Cameron KM. and Fu CX, A phylogenetic analysis of the Smilacaceae based on morphological data, Acta Phytotax. Sin, 44.2 (2006): 113-125.

3. Koyama T, A Taxonomic revision of the genus Heterosmilax (Smilacaceae), Brittonia 36.2 (1984):184205.
4. Hooker JD, Liliaceae in Flora of British India. [Hook. J.D.(ed.)], Vol. 4. L. Reeve \& Co., London, 1886: 708-711.

5. Baruah S and Borthakur S, Smilax lanceifolia Roxb. (Smilacaceae) -a new record to the Flora of Assam, NeBIO, 4.3 (2013): 19-21.

6. Baruah S, Borthakur SK., Gogoi P and Ahmed M, New distributional record of Smilax china Linnaeus in India, Pleione, 5.2 (2011): 325-327. 
7. Baruah S, Borthakur SK and Ahmed M, Taxonomic status of certain members of Smilax Linnaues (Smilacaceae) based on foliar epidermal structure, Pleione, 6.1(2012):87-93.

8. Baruah $\mathrm{S}$ and Borthakur SK, New record of two species of Smilax L. (Smilacaceae) from Assam, India. J. Econ. \& Taxon. Bot., 38.2(2014):227-231.

9. Baruah S, Taxonomic study and habitat distribution modelling for reintroduction of Heterosmilax japonica Kunth. - a rare species of northeastern India. NeBIO, 7.3(2016):101 - 107.

10. Howard RA, The genus Smilax in the Lesser Antilles, Taxon, 28 (1979): 55-58.

11. Agbagwa OI and Ndukwu BC, The valve of morphoanatomical features in the systematic of Cucurbita L. (Cucurbitaceae) species in Nigeria, African Journal of Biotechnology, 3.10 (2004): 541-546.

12. Akcin OR, Ozyurt MS and Senel G, Petiole anatomy of some lamiaceae taxa, Pak. J. Bot., 43.3(2011): 1437-1443.
13. Eric TJ, Michael VA and Linda WE, The importance of petiole structure on inhabitability by ants in Piper sect. Macrostachys (Piperaceae). Botanical Journal of the Linnean Society, 153.2 (2007): 181-191.

14. Ogundare CS and Saheed SA, Foliar epidermal characters and petiole anatomy of four species of citrus L. (Rutaceae) from south-western Nigeria. Bangladesh J. Plant Taxon, 19.1(2012): 25-31.

15. Olowokudejo JD, Taxonomic value of petiole anatomy in the genus Biscutella L. (Cruciferae), Bull. Jard. Bot. Nat. Belg., 57(1987): 307-320.

16. Radford AE, Dickison WC, Massey JR and Bell CL, Vascular plant systematic, Harper and Raw publishers, New York, 1974.

\section{Cite this article as:}

S. Baruah, D. Baro and S. K. Borthakur. Petiole anatomy of Indian species of the genera Smilax L. and Heterosmilax Kunth. (Smilacaceae). Annals of Plant Sciences 6.10 (2017) pp. 1690-1693.

do : http://dx.doi.org/10.21746/aps.2017.10.1 